\title{
Institutional policy learning and formal Federal-urban engagement in Canada
}

\section{Commonwealth Journal of Local Governance}

Issue 7: November 2010

http://epress.lib.uts.edu.au/ojs/index.php/cjlg

\section{Zachary Spicer}

Department of Political Science

The University of Western Ontario, Canada

\begin{abstract}
Canada has experienced two formal federal ministries dedicated to addressing urban issues. The first, the Ministry of State for Urban Affairs, encountered resistance from provincial governments and its fellow departments. Both worked to undermine it. The second, the Ministry of State for Infrastructure and Communities, was created with a more conciliatory tone towards the provincial governments and its ministerial colleagues. This paper examines the establishment of both ministries and tracks their efforts using a policy learning and lesson-drawing framework, concluding that common institutional actors, such as the Privy Council, were responsible for the Ministry of State for Infrastructure and Communities' change in tone and approach to multilevel governance. General lessons are drawn about inter-governmental relations and multi-level policy formation in federal systems.
\end{abstract}

\section{Introduction}

In 1971, the Trudeau government announced the creation of the Ministry of State for Urban Affairs (MSUA). The ministry was intended to coordinate urban policy in Canada, but was abruptly dismantled in 1978. In The Ministry of State for Urban Affairs: A Courageous Experiment in Public Administration, H. Peter Oberlander, the former Deputy Minister, argues that the ministry's downfall resulted from a concerted effort by both line ministries and provincial governments to undercut MSUA because they felt its existence threatened or encroached upon their jurisdictions. Nearly thirty years later, Paul Martin’s government created the Ministry of State for Infrastructure and Communities (MSIC) with similar goals to MSUA. MSIC, however, would find more success with provincial governments and its fellow departments, largely because of its more cautious approach to intergovernmental and 
interdepartmental relations. How and why did this change in direction and policy occur? Did the experiences of MSUA shape the direction of MSIC? Or was the more cautious nature of MSIC the result of thirty years general experience with intergovernmental and interdepartmental interaction?

This paper examines and tests two hypotheses through primary document analysis and interviews conducted with ministry officials. The first hypothesis argues that institutional policy learning was occurring, and once Martin’s government began to address urban issues, it employed a concerted strategy to avoid the perceived failures of MSUA. The alternative hypothesis argues that the altered approach of MSIC was merely the result of thirty years of general institutional experience with intergovernmental and interdepartmental interaction.

\section{Policy Learning}

Policy learning can be seen as the result of efforts to improve or enhance policy-making based on the assessment of past experiences (Etheredge and Short 1983; Sabatier 1988; Rose 1988). There are two views of this process. Peter Hall (1993) introduces us to 'endogenous learning'. Hall defines this activity as a "deliberate attempt to adjust the goals or techniques of policy in the light of the consequences of past policy and new information so as to better attain the ultimate objects of governance” (Hall 1993:278). By contrast, Hugh Heclo (1974) argues that learning is more of a government response to exogenous change in a policy environment. In these terms, learning is more a reaction on the part of governments to new situations, albeit taking into account their past experience.

Bennett and Howlett (1992) find both stark differences and similarities between these two paradigms. They ask three distinct questions about each approach: who learns, what do they learn and to what effect? Based on these three questions, Bennett and Howlett create three typologies: government learning, lesson-drawing and social learning (1992:289). In the government learning paradigm, state officials conduct policy learning in order to effect organizational change. In the lesson-drawing typology, policy networks learn to effect program change, whilst social learning involves broader policy communities (groups of stakeholders) who influence policy paradigms (Bennett and Howlett 1992:289). 
Andrew Stritch (2005) explores a contemporary example of policy learning in his examination of the origins of Quebec's worker compensation programming. Stritch explains that policy learning can be broadly defined as a process of evaluating new policy ideas, past practices and foreign precedents in the policy creation process (2005:553). It can thus be seen as a process of research and evaluation. Stritch further explains this process: "[governments] learn from the shortcomings of pre-existing programmes and practices in their own jurisdiction; they learn from the precedents of other jurisdictions; and they learn from the articulation of interests by societal participants in the course of the policy-making process” (2005:554). In this way, Stritch has provided a bridge for the endogenous and exogenous camps to cross: learning can take place based on both environmental and internal variables.

While Stritch provides the broader definition of policy learning, the term requires operationalization. Two direct criteria for observing policy learning would need to occur. First, there would need to be recognition of previous policy work in the field. This can take several forms, such as a formal review of previous policy efforts in the field or informal acknowledgement of an understanding of past policy processes by ministry officials. It would involve a concerted effort to recognize successes and failures of past policy experiences. The second criteria would be an intentional effort to avoid the noted failures and emulate the successes of past policy efforts in the field. Policy learning can thus be operationalized as a process of evaluating the successes and failures of past policy processes while utilizing such information to improve contemporary policy creation and implementation. Uncovering policy learning therefore depends upon finding 1) a recognition of previous policy efforts in the field and 2) a concerted effort to avoid the failures and emulate the successes of the past policy paradigm.

\section{The Ministry of State for Urban Affairs}

The creation of MSUA was announced on June 30, 1971 with the stated goal of "the development and application of policies to influence the urbanization process” (MSUA 1972:1). The role of the ministry was seen as limited to planning, coordination and research functions and its activities were restricted mostly to enhancing cooperation between different levels of government, as evidenced by the tri-level meeting that MSUA organized in Toronto 
in 1972 (MSUA 1973:i). Despite this limited mandate, the provincial governments were apprehensive. MSUA aroused the suspicions of the provinces, who believed that MSUA was an attempt to impinge upon traditional areas of provincial jurisdiction (Feldman and Graham 1979:xvii). Because of these early suspicions, the provinces were initially reluctant to participate in any sort of tri-level meetings that addressed urban affairs (Feldman and Graham 1979:xix). Eventually the provinces agreed to meet, but the assembled provincial representatives made it clear that they would not tolerate any interference in their jurisdiction. Saskatchewan Premier Alan Blakney spoke on behalf of the provinces by stating that: "we want our constitutional rights respected" (Watkins 1972:3). The federal government was on notice: tread carefully when addressing urban issues.

During the1973-74 fiscal year, the ministry undertook a number of significant research projects, such as examining urban waterfronts, rail links in city centres, municipal financing, and urban management training studies (MSUA 1974:9). There was also a renewed focus on interdepartmental and intergovernmental cooperation within this period, while the scope of the ministry's intergovernmental meetings increased. The President of the Canadian Federation of Mayors and Municipalities was established as a co-chair of the next tri-level meeting (MSUA 1974: 9). Tri-level meetings eventually became policy specific to each province, focusing on issues such as housing and environmental sustainability (MSUA 1974: 9). MSUA held metropolitan tri-level meetings in Halifax-Dartmouth, Quebec City, Vancouver and Winnipeg intended to address issues specific to each city, such as regional growth in Halifax-Dartmouth and Quebec City, the development of transportation hubs in Vancouver, and organizational development for municipal administrators in Winnipeg (MSUA 1974:4).

During 1973-74, MSUA also had an increased focus on inter-departmental cooperation. For example, early in 1973, MSUA initiated a committee with the Ministry of Finance to compile a database of municipal property tax rates across the country (MSUA 1974:5). Later, in July 1973, the Senior Interdepartmental Committee on Urban Affairs was established, which brought together 15 administrators from different departments, such as the Treasury Board, Finance, and Public Works, and was chaired by the Secretary of MSUA (MSUA 1974:2). Then minister, Ron Basford, was clear about how he viewed MSUA. To 
Basford, the ministry's main role was coordination, not funding: "We cannot deal with urban problems merely by transferring more and more money from one pocket to another” (Barker 1973:9).

Basford was replaced by Barney Danson in 1974. The ministry maintained its focus on intergovernmental and interdepartmental cooperation, but such efforts remained relatively stagnant. The national, provincial and municipal tri-level meetings remained in place, as well as the inter-departmental working groups and the Senior Interdepartmental Committee on Urban Affairs, but the ministry was less active in these areas. Its focus began to shift towards specific project funding, a departure from Basford's view that MSUA should be a coordinating and not a funding ministry.

Project funding began to increase in 1974-75. MSUA got heavily involved with land-use planning and helped in the construction of various urban projects, either in a financial or advisory role. Thus in 1974-75, MSUA helped Toronto develop its waterfront; in Calgary it assisted in the design and development of 400 acres of publicly held land; and in Vancouver it supported the expansion of the city's airport (MSUA 1975:4). This focus on project funding was maintained through 1975-76, with support to the Greater Vancouver Regional District, the City of Toronto and Halifax-Dartmouth (MSUA 1976:2).

In 1976, Andre Ouellet replaced Danson and quickly began reducing the size of the ministry and reorganizing its internal operations (MSUA 1977:13). Instead of having a number of separate departments, two were created: Urban Analysis and Urban Coordination (MSUA 1977:4). Urban Analysis handled interdepartmental urban-related policy and research, while Urban Coordination communicated with municipalities and other governments (MSUA 1977: 13). In every province, this coordination increased. For example, in Newfoundland, the ministry assisted with regional growth and development, and in Ontario it helped to force the arbitration of unused public land, assisted Toronto in the planning of a new waterfront, coordinated activities in railway redevelopment, and arranged the relocation of several army bases (MSUA 1977:5). This pattern continued through 1977-78. 
Over its lifetime, the positioning of MSUA changed. The 1973-74 report states that the primary role of the ministry was "urban policy planning”, which would be accomplished through policy development, urban research and coordination with different levels of government (MSUA 1974:i). In 1974-75, MSUA began describing itself as an agency designed for “formulating a set of national objectives for Canada's future urban development” (MSUA 1975:1). In 1975-76, the ministry’s focus turned to the “development of urban-sensitive federal public-policy” (MSUA 1976:1). By 1977-78 the tone and mission had changed once again, the MSUA annual report noting that the ministry was primarily a "coordinating agency of the federal government concerned with ensuring, as far as is possible, that federal policies, programs and projects are undertaken with an awareness of their implications for the social, cultural and economic well-being of urban areas in Canada” (MSUA 1978:3). This reflected an earlier shift in government policy. MSUA's 1976-77 report had included a preface entitled "The Federal Role in Urban Affairs" which stated:

Constitutionally, responsibility for Canada's municipalities and matters of local concern rests solely with the provincial and municipal governments. The federal government recognizes and supports this arrangement. The federal government also recognizes that it has constitutional responsibilities to carry out, and in doing so, federal policies, programs and projects affect the pattern, economic base and quality of life in Canadian settlements. This situation means that the federal government, given its concern with how it affects all Canadians, has a responsibility to ensure that its activities are beneficial to urban areas and that federal initiatives take into account provincial and local objectives and plans (MSUA 1977:3).

The 1977-78 report took a more cautious tone towards the provinces, stating that "the ministry cooperates with other federal departments and agencies, the provinces and, through them, their municipalities" (MSUA 1978:3). It continued: "the purpose of such cooperation is to seek provincial and municipal views and policy positions on urban issues" (MSUA1978:4). Thus over time, we see the tone of the ministry softening as it attempted to convince the provinces that it was respecting their jurisdiction. The gradual emergence of the provinces role within MSUA's mandate reflects the criticism the ministry was receiving. It evidently felt the need to reiterate that it was not a lone actor in this policy field.

Nevertheless, in November 1978 it was announced that MSUA would close the following year. Through its lifetime, MSUA had passed through a number of stages, beginning first as a forum for discussion and coordination, before moving onto direct project funding. When 
direct project funding increased, so did the ire of the provinces, who began to feel threats to their jurisdiction. Oberlander (1987) has provided an account of the intergovernmental tension faced during his tenure as Deputy Minister of MSUA. Recounting provincial-federal relations, Oberlander states the following:

The Provinces, having been alerted to the increasingly strong Federal position in urban issues, perceived a dire threat in a Federal/municipal alliance on urban affairs and demanded their explicit and exclusive Constitutional jurisdiction and ultimately succeeded in undercutting MSUA. The Ministry was offered up upon the altar of Federal-Provincial relations. (Oberlander and Fallick 1987:132)

Of the two areas that Oberlander identified as factors contributing to MSUA's decline, intergovernmental tensions were the most public. Interdepartmental tension, the second factor identified by Oberlander as a cause of the ministry's downfall, was less publicized and more challenging to account for. According to Oberlander appeared to raise tensions (Oberlander and Fallick 1987:131). Oberlander uses the urban transportation policy as an example: "as MSUA offered advice in the field of transportation and its impact on urbanization and regional development, eg: Toronto Airport II and Mirabel, the Ministry of Transport felt threatened and felt its advice undercut at Cabinet level” (Oberlander and Fallick 1987, 131). Such tensions are not documented in annual reports and rarely find a place in the national media, which is why Oberlander's candid commentary is invaluable in understanding why MSUA was so abruptly dissolved.

\section{The Ministry of State for Infrastructure and Communities}

During the 2000 election, the Liberal policy platform contained a promise to establish a Prime Minister's Task Force on Urban Issues (Globe and Mail 2002, A14). Soon after the election, the Prime Minister's Task Force was established with Toronto MP Judy Sgro as Chair (Winsor 2002, A4). The Caucus Task Force report argued that the government must implement a national urban strategy that would balance municipal rights and responsibilities with those of the federal government, providing investment in urban centres. The report states that this urban strategy would entail: "an enhanced relationship between the Government of Canada and among our urban partners, provincial and municipal governments, the private sector, community and business leaders and the voluntary sector" (Prime Minister's Caucus Task Force on Urban Issues 2002:5). The government planned on being only one part of this national strategy, not the lead. Thus the report talks of a national 
urban partnership that "will guide strategic federal capital-investment in our cities and will improve the quality of life for millions of Canadians living in our urban regions” (Prime Minister's Caucus Task Force on Urban Issues 2002, 5). The federal government would enter into projects with municipalities as long as such projects complied with basic federal guidelines, such as enhancing the quality of life, conforming with standards of fiscal accountability, and contributing to sustainable development (Prime Minister’s Caucus Task Force on Urban Issues 2002: 7).

The task force recommended that a cabinet minister be designated with the responsibility of coordinating the federal government's efforts and investments in urban centres (Prime Minister's Caucus Task Force on Urban Issues 2002, 8). At the same time, this individual would act as the "voice" for cities around the cabinet table, ensuring that the federal government could not overlook pressing urban issues (Prime Minister's Caucus Task Force on Urban Issues 2002:8).

The task force's report went largely unfulfilled during the end of Jean Chrétien's term as Prime Minister, and Chrétien instructed the task force to avoid specific commitments (Winsor 2002, A4). Clearly worried about a provincial backlash towards federal efforts, Chrétien, upon being questioned about his task force's efforts, stated that: "the cities are under provincial responsibility; we are not in a position to give them more power" (Winsor 2002, A4).

As the task force did its work and while Finance Minister Paul Martin was suggesting a 'new deal' for cities, the provinces were providing warnings to the federal government to tread carefully. Ontario Finance Minister Janet Ecker warned the federal government to not address taxation powers (Lewington 2002, A6). "We are willing to join the emerging dialogue about a new deal for cities - if it's the right one,” stated Ecker, showing both enthusiasm and restraint about the prospects of a renewed federal-municipal urban strategy (Lewington 2002, A6). Ecker stated that any new taxing authority for municipalities had to come with a "precondition" between the federal government and the provinces that would "restore the balance between revenue and funding responsibilities for all levels of government in Canada” (Lewington 2002, A6). 
Even with provincial concerns noted, Chrétien had an interest in urban issues, as evidenced through his $\$ 76$ million urban transit grant to the City of Toronto and his commitment to improve urban housing (Winsor 2002, A4). The Office of Infrastructure and Crown Corporations was created in 2002, with a mandate to coordinate the public service's existing infrastructure (Forster 2010). The 2002 budget allowed for the creation of the Canadian Strategic Infrastructure Fund (CSIF) (Juneau 2010). The decision initially had to be made of whether to establish a foundation to distribute the funds from the CSIF or to create a small, bureaucratic department (Juneau 2010). In the end, with the input of senior public servants, the government opted to create a small department housed in the Treasury Board with responsibility for the portfolio assigned to cabinet minister Allan Rock (Juneau 2010).

Chrétien was interested in assisting Canada's cities but was unwilling to create a formal department to address urban issues. Paul Martin, however, was willing, although his proposed 'new deal' was short on specifics and he rejected the notion of sharing gas tax revenue very early on (Scoffield 2002a). “The finance minister did not offer any money...he offered understanding," stated Jack Layton, then the President of the Federation of Canadian Municipalities. "He sympathizes with our problem, he is concerned about our problem, but there was a remarkably empty chequebook in the discussion” (Scoffield 2002a).

While running for the leadership of the Liberal Party, Martin began to address specifics about his 'new deal'. Martin argued that Ottawa should cede some taxation sources to municipalities so that cities would not have to rely on property tax as a main source of revenue (Scoffield 2002b, A4). "Property taxes were meant for snow removal and garbage collection," stated Martin, "they were not meant to take on the vast range of social programs cities face today" (Scoffield 2002b, A4). Additionally, Martin's plan would rely on the creation of government programs that would address urban issues, such as direct funding mechanisms (Scoffield 2002b, A4). Martin, much like Chrétien, was aware of provincial concerns about taxation and programming, as his 'new deal' was criticized by the government of Quebec as a way of siphoning money away from the province's health and education services (Scoffield 2002b, A4). "Without the full co-operation of the provinces," stated Martin, “a ‘new deal' doesn’t have a chance to get off the ground” (Scoffield 2002b, 
A4). Much like Chrétien, Martin knew that he would have to tread carefully in the face of provincial demands, although he still planned to push ahead with his ambitious program.

Upon becoming Prime Minister in 2003, Paul Martin began to fulfill his 'new deal' vision, appointing a parliamentary secretary to the Prime Minster with sole responsibility for urban issues (Plunkett 2004:23). While this step fell short of the full cabinet minister recommended in the 2002 task force report, it was still seen as a positive step forward (Plunkett 2004, 23). Martin selected Toronto MP John Godfrey to be the new parliamentary secretary with an emphasis on cities (Globe and Mail 2003, A13). Godfrey's role was still ambiguous at this time, a fact that Godfrey himself readily acknowledged, but one that came with a direct mandate to listen to mayors and city councils, recommend solutions to the government and implement federal policies, negotiating with the provinces to ensure the approval of all levels of government (Rusk 2003, A18). Godfrey acknowledged the role of the provinces upon assuming the post: "we've got to work with the provinces to come up with goals that all three levels of government would say 'that's right'” (Rusk 2003, A18).

Godfrey spent the next several months meeting with provincial leaders, ensuring they were comfortable with Martin's proposed revised relationship with cities, commenting that: "what we want to do is the maximum possible to work together in partnership with the provinces" (Lewington 2004, A14). However, even with that noted, Godfrey stated that he would be prepared to move forward with the plan even if not all the provinces approved (Lewington 2004, A14).

Martin also established a fifteen-member committee, chaired by former British Columbia Premier Mike Harcourt, that would oversee the implementation of the 'new deal' along with a permanent cities secretariat based out of the Privy Council Office that would oversee urban spending (Globe and Mail 2004, A12). Martin’s first budget began the process of changing the relationship between the federal government and cities. Martin eliminated the Goods and Service Tax on municipal expenditures and increased the amount of federal resources available to municipalities to nearly $\$ 7$ billion (Liberal Party of Canada 2004:9). 
As Martin headed into the 2004 election, he added to his existing urban plan through the Liberal Party platform, entitled Moving Canada Forward. The Liberal platform stated that if re-elected, municipalities would be included in pre-budget consultations, tripartite agreements would be extended, and municipalities would be provided with a share of the federal gas-tax (Liberal Party of Canada 2004:9). The language contained in Moving Canada Forward speaks of partnership and inclusion amongst all three levels of government. All three levels of government are described as "partners" and federal efforts are described as “co-operative” (Liberal Party of Canada 2004:9). At no point in Moving Canada Forward are the federal government's efforts in municipalities described as one-sided.

Soon after the election, Martin announced the creation of the Ministry of State for Infrastructure and Communities (MSIC) and appointed his former parliamentary secretary for urban issues, John Godfrey, to be the department's first minister (Clark and Lewington 2004, A7). Godfrey built on his work as parliamentary secretary and began to implement many of the initiatives described by Martin during the election campaign. Godfrey clarified his role in regard to the provinces: "The job now becomes to work with the provinces...in consultation with the municipalities to find a formula which advances the needs of the municipalities” (Taber 2004, A1).

Godfrey's tone was deliberate. He, and the senior bureaucrats who established MSIC, knew that if the ministry was not established as collaborative it would not succeed. Some initial ground rules were established when approaching the provinces. The most important rule was that communication was established as an exclusive two-way channel between the federal government and the provinces (Juneau, 2010). The federal government would never negotiate with cities or their provincial municipal associations, unless a province requested it (Juneau 2010). Nor would they seek input about projects from cities or invite cities to identify potential infrastructure projects (Juneau 2010). British Columbia and Ontario were the exceptions to this rule, as both provincial governments requested that MSIC negotiate the gas tax transfer directly with their provincial municipal associations (Juneau 2010). MSIC intended to telegraph a simple message to the provincial governments: the Ministry of State for Infrastructure and Communities was interested solely in cooperation with the provinces, not municipalities. 
MSIC released its first annual report in the 2004-2005 fiscal year. The report acknowledged the earlier actions of the Martin government's 'new deal', including GST rebates and the creation of the Cities Secretariat though the Privy Council, but made specific reference to "partnerships with [the] provinces” and “consultations with municipalities” (Infrastructure Canada 2004: 8). This positive tone continued as the report addressed previous government efforts to fund infrastructure: the Canada Infrastructure Works Program in 1994; the Infrastructure Canada program in 2000; the Canada Strategic Infrastructure Fund in 2003; the Prairie Grain Roads program in 2001 (Infrastructure Canada 2004, 8). Overall, the report noted over \$12 billion in infrastructure investment since 1993 (Infrastructure Canada 2004, 10). The intended message from this historical overview is simple: MSIC is merely providing a formal face to the investment completed by the governments of Paul Martin and Jean Chrétien.

This initial report also laid out the new department's mandate. The report notes that: "an important part of [the Ministry's] mandate is to coordinate and manage funding programs that support public infrastructure initiatives, provide strategic advice and policy direction.” It continues: "Infrastructure Canada concentrates on policy development and on research...it is also responsible for communications and dissemination of information on the federal role and contributions to infrastructure in Canada” (Infrastructure Canada 2004:11). On the coordination side, the ministry was clear that it was coordinating federal policy and aligning the needs of municipalities through several federal agencies, such as the Atlantic Canada Opportunities Agency, Western Economic Diversification Canada, Canada Economic Development for Quebec Regions, Industry Canada and Indian and Northern Affairs Canada (Infrastructure Canada 2004:12). Much of this was similar to the previous Ministry of State for Urban Affairs in its initial mandate: it had coordinated policy activities amongst various actors, but specifically focused on policy coordination at the federal level.

Where MSIC differs greatly from MSUA is in its approach to funding. MSIC’s first report is clear in its funding expectations and responsibilities: "provinces and municipalities are the managers of the projects while Infrastructure Canada provides policy leadership and horizontal coordination of project implementation” (Infrastructure Canada 2004:12). The ministry worked with the provinces and municipalities to identify "priority projects" and 
from there, all three parties would: "clarify the scope and nature and funding mechanisms of these projects” (Infrastructure Canada 2004:11). Once a project is identified and approved, an environmental assessment and other procedures were completed and then a federalprovincial/territorial management committee was established and a Memorandum of Understanding was signed to clarify the roles and responsibilities of both the provinces and the federal government (Infrastructure Canada 2004, 11).

Thus from the inception of MSIC, the provinces and municipalities were in the driver's seat, not the federal government - a clear and critical difference from previous efforts with formal federal engagement in the municipal sphere. The federal government alone was not identifying projects. Provincial involvement was not only encouraged but also demanded and sustained.

MSIC's 2005-2006 annual report mirrored the 2004-2005 report in tone and objectives, reiterating the ministry's restrained approach to intergovernmental relations by stating that:

Constitutionally, municipalities are under provincial jurisdiction. Respect for this jurisdiction is a central principle of the New Deal. The complex challenges that play out in cities and communities require a coordinated approach if workable solutions are to be found. A partnered approach is essential and approaches must be tailored to address the circumstances of different communities: urban and rural, large and small (Infrastructure Canada 2005:10).

The interdepartmental strategy employed by MSIC was also significantly different from that of MSUA. The former Assistant Deputy Minister for MSIC notes that there was an initial fear about interdepartmental tensions, so the ministry met to figure out a way to manage expectations and ministerial "shopping lists" (Laroche 2010). MSIC was a funding ministry, with a budget allotment that was expected to reach more than $\$ 5$ billion dollars over a fiveyear period and nearly every ministry wanted a portion of it for their own projects (Laroche 2010). Its solution was to focus on one guiding policy area: in this case, environmental sustainability. Every project that MSIC approached or approved had to be related to environmental sustainability and had to contribute to Canada reaching its Kyoto Agreement targets (Laroche 2010). Additionally, MSIC was clear that it would not consider or fund federal projects, which eliminated the possibility of funding the particular projects of different departments (Juneau 2010). 
To ensure that MSIC's relationship with other ministries was maintained, two committees were established: an interdepartmental infrastructure committee and an Assistant Deputy Minister working group. Both groups included representatives from MSIC together with Environment Canada, Treasury Board, Heritage Canada, the Privy Council Office, Intergovernmental Affairs, Human Resources and Skills Development, Agriculture, Industry Canada, and the regional development offices (Laroche 2010). These ongoing committees allowed MSIC to manage expectations and maintain effective communication with its fellow departments.

With these procedures in place, André Juneau, the former Assistant Deputy Minister recalls only small amounts of tension with the Ministry of Transport. For the most part, their portfolios were interdependent. In cases of conflict over a certain project, MSIC would work in consultation with the Ministry of Transport: (Juneau2010). MSIC would be responsible for the funding, while Transport would be responsible for the negotiation process (Juneau 2010). The current associate Deputy Minister for Infrastructure with Infrastructure Canada confirms that these strategies are still in place (Forster 2010).

The 2006 federal election saw Paul Martin voted out of office. With Martin went any sense of enthusiasm to actively engage cities and communities. In his place, Stephen Harper and his Conservative party sought to run a leaner government and operated on the principles of 'open federalism'. The Ministry of State for Infrastructure and Communities was amalgamated with the Ministry of Transportation to create the revamped Ministry of Transport, Infrastructure and Communities. The rationale behind this consolidation was efficiency: "bringing the various tools and policy levers of this portfolio under the responsibility of a single minister offers great potential for strategic and coherent policy development” (Infrastructure Canada 2006:1). The minister responsible for the department, Lawrence Cannon, was just as positive about the amalgamation, stating that: "I believe that the alignment of Infrastructure Canada with Transport Canada and the Crown corporations will provide a tremendous opportunity to integrate federal efforts and address the pressing and long-term issues facing Canadians and our communities” (ibid). Additionally, the government stated that the amalgamation would allow the department to cooperate more efficiently with the provincial and municipal governments (Infrastructure Canada 2006:5). 


\section{Did Policy Learning Occur?}

To determine if policy learning was present when constructing the Ministry of State for Infrastructure and Communities, two criteria were established: 1) a recognition of previous policy efforts in the field and 2) a concerted effort to avoid the failures and emulate the successes of the past policy paradigm.

\section{Recognition of previous policy efforts}

Comments referencing MSUA in the media by members of the Chretien-Martin government are rare. From the outset, their government attempted to clarify its goals and aims in the urban policy realm. Chretien (Winsor 2004), Martin (Scoffield 2002b) and Godfrey (Rusk 2003; Lewington 2004) were clear about the federal role in relation to the provinces. All three acknowledged that the provinces, constitutionally, had sole control of municipal affairs. They argued that existing federal policy had implications in the municipal sphere and, as such, a coordinating ministry should be created to enhance the effectiveness of those policies.

Aside from a brief mention in its initial annual report, MSUA is not formally mentioned in MSIC documentation. However, André Juneau, the former Deputy Head of MSIC, provides some insight. Juneau states that those in the original Office of Infrastructure assembled a strategy to approach the provinces acknowledging that MSUA “antagonized the provinces", and argued that "the constitution must be respected" (Juneau 2010). To Juneau, and many of those involved with the creation of MSIC, MSUA had not had a large impact and failed to change the course of urban Canada (Juneau 2010). Yazmine Laroche agrees with much of this assessment, acknowledging that those involved with the establishment of MSIC were not looking to "reinvent the wheel” (Laroche 2010). They knew that MSIC had to take a more collaborative approach with both the provinces and its fellow departments.

\section{An effort to avoid the failures and emulate the success of the past policy paradigm}

While federal political actors worked to reassure the provinces that their role in municipal affairs was not threatened, the Prime Minister's Task Force on Urban Issues began an effort to emulate the successes of MSUA. The task force made it clear that coordination, collaboration and consultation were cornerstones of the new ministry. "We live in an era of 
policy interdependence," the report stated, "where actions of one order of government have an effect on other governments” (Prime Minister's Caucus Task Force on Urban Issues 2002:6). MSUA had found success when it initially established itself as a forum for discussion and coordination, but when it began to fund projects the provinces became concerned about their jurisdiction. The task force felt the need to emphasize that early success.

The task force also emphasized eight responsibilities that a designated urban affairs minister should hold, including chairing and coordinating a National Urban Summit with First Ministers and urban policy advocates, coordinating policies between different federal ministries, and creating an external urban affairs advisory body (Prime Minister's Caucus Task Force on Urban Issues 2002:8). All three recommendations echoed the early successes of MSUA, such as the tri-level meetings, the inter-departmental collaboration and urban working groups.

At the departmental level, MSIC made it clear that it would not fund federal projects and that any projects it initiated had to have environmental sustainability as an overarching goal, removing the potential for influence from or interdependence with many line departments. The only ministry that MSIC occasionally came into conflict with was the Ministry of Transport. For the most part, these disagreements were solved amicably through project sharing: Transport would lead the negotiations and MSIC would lead the efforts to fund the project. Two working groups were established to ensure "buy in" from other departments, managing their expectations and maintaining open channels of communication (Laroche 2010).

Once created, MSIC made a concerted effort to avoid the failures of MSUA. First and foremost, MSIC designed itself as a partner in a broader urban affairs strategy, not as the lead. The ministry was clear that the provinces were ultimately in control of municipal affairs and that the federal government's role was to provide assistance and coordination where it was feasible. Discussions and negotiations took place only between the federal government and their provincial colleagues. There were no direct negotiations with cities unless sanctioned by provinces. Memorandums of Understanding were struck for each 
project initiated through MSIC to ensure that affected provinces and municipalities understood their role in relation to the federal government and were comfortable with the arrangement. The Finance Minister met with municipalities in pre-budget consultations and kept the provinces informed on their long-term planning in regards to the urban policy realm.

\section{Who learns? When do they learn?}

There was one institutional actor that was common throughout both ministries: the Privy Council Office (PCO). During the MSUA era, the Privy Council was not as active in its operations or decision-making, but as a central agency largely responsible for provincialfederal relations, the Privy Council Office did field the outcomes of MSUA's occasionally conflict-ridden multi-level relations. When tri-level meetings failed and certain provinces did not attend, it was the Privy Council that was responsible for crafting a response (Newman 1987:60). Overtime, the Privy Council Office became more involved with the operations and strategic decision-making of MSUA, in an attempt to "rationalize” planning and policy process (Gertler 1987:110).

When comparing MSUA and MSIC, what is striking is the level of influence the Privy Council had over the process leading up to the creation of MSIC. In 2002, the Task Force on Urban Issues was created in the PCO (Forster 2010) and when it was time to further steps with the Office of Infrastructure and Crown Corporations, it was André Juneau, the Deputy Secretary of Operations for the PCO that was selected to be its lead. The Cities Secretariat, established in 2003, was created within the PCO. After the creation of MSIC, we still see the influence of the PCO in both coordinating MSIC and its fellow departments and provincialfederal relations (Juneau 2010).

The PCO is an institution with a collective memory. Unlike the two ministries themselves, the PCO is consistent throughout both eras. After MSUA was dismantled, many of the employees and managers were dispersed throughout the government, leaving little institutional memory. Other ministries that have endured throughout both eras, such as Transport and Treasury Board, had a minimal amount of interaction with MSUA, especially in their relationship with the provinces, but the PCO, an institutional actor tasked with maintaining the internal and external relationships of the federal government, did. Because of 
this relationship, the PCO took a more active role in the life of MSIC. It acted as an arbiter between MSIC and its fellow departments and ensured that MSIC had a more collaborative relationship with the provinces. Without the Privy Council, and its role as a learner and teacher, MSIC could very well have followed MSUA.

With that said, there is a need to consider the alternative hypothesis put forward at the beginning of this paper, namely that the altered approach of MSIC was merely the result of thirty years of general institutional experience with intergovernmental and interdepartmental interaction. In this case, specialized learning would not occur. One of the problems with the policy-learning paradigm itself is sorting out this general type of learning from specialized learning about specific policy areas. Studying MSUA and MSIC presents just this challenge. There can be no doubt that the years between MSUA's closure and MSIC's inception were tumultuous for Canadian federalism. The rise of regionalism and the strengthening of the provinces marked this time span and when MSIC was created, it would be natural to assume that policy-makers would create the department with these events in mind. The specific changes made, however, would indicate that a very specific type of learning was in fact occurring.

Interdepartmental and intergovernmental relations were identified as factors that contributed to MSUAs downfall. In both cases, those tasked with creating MSIC took proactive steps to correct what were seen as past errors. Safeguards were put in place to ensure interdepartmental cooperation, while rules were designed to guide interactions with the provinces. These were specific measures to avoid what policy-crafters viewed as MSUA's failures.

\section{Conclusion}

The Ministry of State for Urban Affairs began as a coordinating ministry but quickly moved into direct project funding within municipalities, often at the exclusion of the provinces. Other ministries in the federal government also feared jurisdictional intrusion on the part of MSUA and worked internally to undermine its efforts. These two factors worked against MSUA and it was eventually shut down. MSIC, on the other hand, remained a coordinating ministry and did not enter into project funding without provincial approval. Tensions were 
reduced with other ministries through a system of sharing project leadership, reducing the interdepartmental friction that Oberlander argues ultimately led to MSUA's downfall.

It has been argued (Levy 1994; May 1992) that policy failure, either real or perceived, strongly influences future policy paradigms. In this case, there is a convincing argument that the comparison between MSUA and MSIC reflects policy learning. The Privy Council, once tasked with sustaining the relationship between Ottawa and the provinces that had been strained by MSUA's entrance into the urban sphere, worked to ensure that MSIC's relationship with not only the provinces, but also its fellow departments, would be different. Thus the two conditions of institutional policy learning, addressed earlier, were present with the creation of MSIC which recognises previous policy efforts and an effort to avoid past failures and emulate past successes. Those involved with MSIC argued that they wanted to create a ministry with a more positive approach towards the provinces and their fellow departments. The institutional knowledge necessary to put this change into practice, however, came from the Privy Council Office.

\section{References}

Barker, A. 1973. “Ottawa Won’t Play Banker’s Role in Urban Problems, Basford Says.” Globe and Mail (national edition), 5 June: 9.

Bennett, Colin J.. and Michael. Howlett. 1991. "The Lessons of Learning: Reconciling Theories of Policy Learning and Policy Change.” Policy Sciences 25 (3) August: 275-294.

Bovens, Mark and Paul t’Hart. 1996. Understanding Policy Fiascoes. New Brunswick: Transaction Press.

Clark, C. and J. Lewington. 2004. "Big Cities Dislike Proposal for Dividing Cash.” Globe and Mail (national edition), 29 July: A7.

Etheridge, Lloyd S. 1981. "Government Learning: An Overview," in The Handbook of Political Behaviour, Vol. 2, eds. Samuel L. Long. New York and London: Plenum Press,

Ethridge, Lloyd S. and James Short. 1983. "Thinking About Government Learning,” in Journal Of Management Studies, Vol. 20, No. 1.

Feldman, Lionel D. and Katherine A. Graham. Bargaining for Cities: Municipalities and Intergovernmental Relations: An Assessment. Toronto: Institute for Research on Public Policy, 1979.

Forster, J. 2010. Personal interview with Associate Deputy Minister, Infrastructure Canada, 16 March.

Gertler, Len. 1987. “Research Based Urban Policy,” in The Ministry of State for Urban Affairs: A Courageous Experiment in Public Administration, eds. H. Peter Oberlander and Arthur 
L. Fallick. Vancouver: UBC Press.

Globe and Mail. 1976. "Danison Will Contact Provinces on Housing Warranty Programs." Globe and Mail (national edition), 30 January: B3.

Globe and Mail 2002. “A Little Something for Canada’s Cities.” Globe and Mail (national edition), 3 May: A14

Globe and Mail 2003. "Parliamentary Secretaries Will Report to Martin.” Globe and Mail (national edition), 13 December: A13.

Globe and Mail 2004. "Martin’s Cities Agenda Belongs in Major Cities.” Globe and Mail (national edition), 20 August: A12.

Hall, Peter. 1989. "Conclusion: The Politics of Keynesian Ideas,” in The Political Power of

Economic Ideas: Keynesianism Across Nations, eds. Peter A. Hall. Princeton:

Princeton University Press.

Hall, Peter. 1993. "Policy Paradigms, Social Learning and the State: The Case of Economic

Policy Making in Britain,” in Comparative Politics, Vol. 25, No. 3.

Howlett, Michael and M. Ramesh. 2003. Studying Public Policy: Policy Cycles and Policy

Subsystems. Toronto: Oxford University Press.

Infrastructure Canada. 2004. Report on Plans and Priorities. Ottawa:

Government of Canada.

Infrastructure Canada 2005. Report on Plans and Priorities. Ottawa: Government of Canada.

Infrastructure Canada 2006. Report on Plans and Priorities. Ottawa; Government of Canada.

Juneau, A. 2010. Personal interview with former Deputy Minister, Ministry of State for Infrastructure and Communities, 26 March.

Laroche, Y. 2010. Personal interview with former Assistant Deputy Minister for Cities and Communities, Ministry of State for Infrastructure and Communities, 26

April.

Levy, J. 1994. "Learning and Foreign Policy: Sweeping a Conceptual Minefield,” in International Organization 48 (2): 279-312.

Lewington, J. 2002. “Ontario Wants Federal Deal Before Altering City Powers.” Globe and Mail (national edition), 18 June: A6.

Lewington 2004. "Ottawa Ready to Move on 'New Deal' for Cities." Globe and Mail (national edition), 25 February: A14.

Liberal Party of Canada. 2004. Moving Canada Forward: The Paul Martin Plan for Getting Things Done. Ottawa: Liberal Party of Canada.

May, P. 1992. "Policy Learning and Failure,” in Journal of Public Policy 12(4):

331-54.

Ministry of State for Urban Affairs. 1972. First Annual Report. Ottawa: Government of Canada.

Ministry of State for Urban Affairs 1973. Rapport Annuel pour L'exercise Financier Termine 31 Mars 1973. Ottawa: Government of Canada.

Ministry of State for Urban Affairs 1974. Annual Report: 1973-74. Ottawa: Government of Canada, 1974. 
Ministry of State for Urban Affairs 1975. Annual Report: 1974-75. Ottawa: Government of Canada, 1975.

Ministry of State for Urban Affairs 1976. Annual Report: 1975-76. Ottawa: Government of Canada. Ministry of State for Urban Affairs 1977. Annual Report: 1976-77. Ottawa: Government of Canada. Ministry of State for Urban Affairs 1978. Annual Report: 1977-78. Ottawa: Government of Canada. Newman, D.G. "The Golden Hour of Municipal Politics," in The Ministry of State for Urban Affairs: A Courageous Experiment in Public Administration, eds. H. Peter Oberlander and Arthur L. Fallick. Vancouver: UBC Press, 1987.

Oberlander, H. Peter and Arthur L. Fallick. The Ministry of State for Urban Affairs: A Courageous Experiment in Public Administration. Vancouver: UBC Press, 1987.

Pal, Leslie A. 2006. Beyond Policy Analysis: Public Issue Management in Turbulent Times. Toronto: Thomson Nielson.

Prime Minister's Caucus Task Force on Urban Issues. 2002. Canada's Urban Strategy: A Blueprint for Action. Ottawa: Government of Canada.

Plunkett, T.J. 2004. "A Nation of Cities Awaits Paul Martin's 'New Deal' - Federal Funds for 'Creatures of the Provinces'.” Policy Options, February 2002, 23.

Rose, R. 1988. "Comparative Policy Analysis: The Program Approach,” in Comparing Pluralist Democracies: Strains on Legitimacy, eds. Mattei Dogan. Boulder: Westview Press.

Rusk, J. 2003. “Godfrey Handed New Cities Post.” Globe and Mail (national edition), 12 December: A18.

Sabathier, P. "An Advocacy Coalition Framework of Policy Change and the Role of Policy Oriented Learning Therin,” in Policy Sciences 211988.

Scoffield, H. 2002a. "Ottawa Promises Cities 'New Deal'.” Globe and Mail (national edition), 19 February: A9.

Scoffield. 2002b. "Urban Funding Dominates Liberal Battles.” Globe and Mail (national edition), 15 July: A4.

Stritch, Andrew. 2005. "Power Resources, Institutions and Policy Learning: The Origins of Workers' Compensation in Quebec,” in Canadian Journal of Political Science 38 (3) September: 549-579.

Taber, J. 2004. “PMO Left Stalwarts Hanging.” Globe and Mail (national edition), 21 July: A1.

Watkins, L. 1972. "Provinces Will Not Tolerate Encroachment on their Rights in Urban Affairs." Globe and Mail (national edition), 4 August: 3.

Winsor, H. 2002. "Urban Problems Prompt an Attack of the Dithers." Globe and Mail (national edition), 2 May: A4. 